\title{
Kaposi's sarcoma in persons living with HIV/AIDS: a case series in a tertiary referral hospital ${ }^{*}$
}

\author{
Carla Andréa Avelar Pires ${ }^{1,2}$, Marcos Antonio Neves Noronha ${ }^{3}$, Julius Caesar Mendes Soares Monteiro ${ }^{4}$, \\ Albert Luiz Costa da Costa ${ }^{5}$, José Maria de Castro Abreu Júnior ${ }^{6}$
}

DOI: http:/ / dx.doi.org/10.1590/abd1806-4841.20186978

\begin{abstract}
BACKGROUnD: Kaposi's sarcoma (KS) is a rare neoplasm with indolent progression. Since 1981, the Kaposi's sarcoma epidemic has increased as co-infection with HIV.

ОвлестIVEs: The study aimed to identify the clinical and demographic characteristics and therapeutic approaches in HIV/AIDS patients in a regional referral hospital.

METHODs: We analyzed the medical records of 51 patients with histopathological diagnosis of Kaposi's sarcoma hospitalized at Hospital Universitário João de Barros Barreto (HUJBB) from 2004 to 2015.

RESUlts: The study sample consisted of individuals 15 to 44 years of age (80.4\%), male (80.4\%), single (86.3\%), and residing in Greater Metropolitan Belém, Pará State, Brazil. The primary skin lesions identified at diagnosis were violaceous macules (45\%) and violaceous papules (25\%). Visceral involvement was seen in $62.7 \%$, mainly affecting the stomach (75\%). The most frequent treatment regimen was 2 NRTI + NNRTI, and $60.8 \%$ were referred to chemotherapy.

STUDY LIMITATIONS: We assumed that more patients had been admitted to hospital without histopathological confirmation or with pathology reports from other services, so that the current study probably underestimated the number of KS cases.

CONCLUSION: Although the cutaneous manifestations in most of these patients were non-exuberant skin lesions like macules and papules, many already showed visceral involvement. Meticulous screening of these patients is thus mandatory, even if the skin lesions are subtle and localized.
\end{abstract}

Keywords: Acquired immunodeficiency syndrome; HIV; Human herpesvirus 8; Kaposi's sarcoma

\section{INTRODUCTION}

Kaposi's sarcoma (KS) is a poorly differentiated mesenchymal neoplasm, first described in 1872 by Moritz Kaposi. ${ }^{1}$ The disease usually presents with tropism for lymphatics and blood vessels of the skin, but it can occur in other organs. There are four subtypes, with different clinical manifestations: 1) classic (Mediterranean or sporadic); 2) endemic (African); 3) iatrogenic (generally in transplant patients); and 4) epidemic (associated with HIV/AIDS). ${ }^{2,3}$
The prevalence of epidemic KS, associated with the human immunodeficiency virus (HIV), increased since the 1980s as a consequence of the spread of HIV infection. It is known as a defining disease for advanced immunodepression. The involvement of human herpesvirus-8 (HHV-8) in the etiology of all subtypes of KS was discovered in 1994. ${ }^{4}$ Today, KS is one of the most common complications of AIDS in industrialized countries. KS occurs in all age groups

\footnotetext{
Received 08 February 2017.

Accepted 08 June 2017.

* Work conducted at Hospital Universitário João de Barros Barreto, Universidade Federal do Pará, Belém (PA), Brazil.

Financial support: Coordenação de Aperfeiçoamento de Pessoal de Nível Superior - CAPES.

Conflict of interest: None.

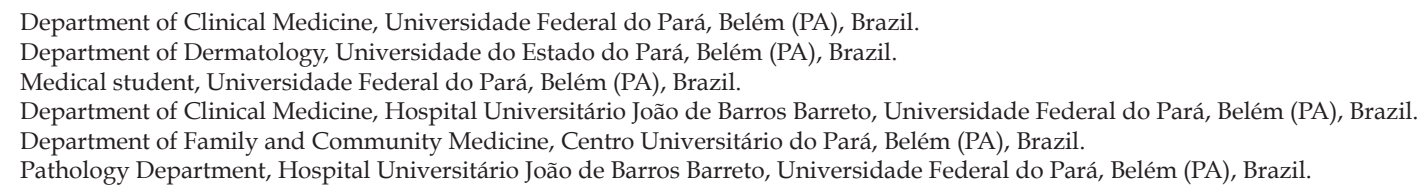


and mainly in men who have sex with men (MSM). ${ }^{5}$ In Brazil, there are more than 800,000 persons living with HIV/AIDS (PLWHA), and $\mathrm{KS}$ is the most frequent neoplasm in this group. ${ }^{6}$ Still, the etiological agent's prevalence differs in the various populations: $1.1 \%$ in previously healthy patients, $20.4-25.9 \%$ in patients coinfected with $\mathrm{HIV}$, and $75.3 \%$ in patients that are descendants of Indians from the Amazon Region. ${ }^{7-9}$

In immunocompetent individuals, the disease usually manifests more in the distal parts of limbs, while in immunosuppressed individuals KS behaves like a multifocal systemic disease. ${ }^{10,11}$ In PLWHA, studies have reported an association with other lymphoproliferative disorders such as Castleman's disease, and this comorbidity can occur even in the presence of continuous antiretroviral therapy (cART), thus emphasizing the need for early diagnosis. ${ }^{12-14}$

Continuous ART is essential for avoiding the emergence of KS or rapid progression of the disease in PLWHA with this diagnosis. ${ }^{15}$ Continuous ART decreased the incidence of KS from approximately $30 / 1000$ cases per patient-year to $0.03 / 1000$ cases per patient-year. $^{3}$

KS is an aggressive disease that leads to death, usually from other complications like opportunistic infections associated with AIDS. ${ }^{16}$ In a study of 112 patients with advanced immunodepression, $65(58.0 \%)$ died from opportunistic infections and eight $(7.1 \%)$ died directly from KS. ${ }^{17-19}$

This article thus aims to identify the epidemiological and clinical characteristics of persons living with HIV/AIDS and KS, admitted to a tertiary referral hospital in the Amazon Region.

\section{METHODS}

A retrospective, cross-sectional case series study was performed in persons with a diagnosis of HIV-1 and concurrent histopathological diagnosis of KS from 2004 to 2015. The study group consisted of patients with histopathological confirmation of KS, treated during hospitalization in the Division of Infectious Diseases of Hospital Universitário João de Barros Barreto (HUJBB) during the study period. Inclusion criteria were: adult age ( $>18$ years), diagnostic confirmation of HIV-1 according to Brazilian Ministry of Health guidelines, and dermatological or endoscopic suspicion of KS with subsequent histopathological confirmation. Exclusion criteria were: patients with incomplete medical charts that prevented meeting the study protocol.

All the clinical, epidemiological, and treatment data and disease history were transcribed from the patient's charts to the study protocol. Pathology reports were obtained from the database of the Pathology Department of HUJBB, and 113 reports were located with histopathological confirmation of KS. However, some reports referred to the same patient, when more than one biopsy had been performed to investigate KS in different organs. After exclusion of duplicates, there were 69 individuals eligible for the study. Still, 18 patient charts were not located, so 51 individuals and their respective charts were analyzed in relation to the variables age, birthplace, current address, occupation, schooling, skin color, and conjugal status. Clinical variables were classified according to the AIDS Clinical Trial Group (ACTG) guidelines for staging patients. Primary lesions were described as recorded on the medical charts, and we also analyzed the antiretroviral regimen and recorded whether the patients had been referred to chemotherapy. ${ }^{19}$

The descriptive analysis, inferences, and graphs used BioEstat 5.3, Epi Info 7, and Microsoft Excel 2010.

The study was approved by the Institutional Review Board of HUJBB, in accordance with resolution 466/2012 of the National Health Council/Ministry of Health (CNS/MS) and only began after the license was granted (case review: 787848/2014; CAE: 34639414.7.0000.0017).

One limitation to the study was possible underestimation of KS cases in the study period, since the sample only included patients with histopathological diagnosis performed at the hospital.

TABLE 1: Distribution of persons living with HIV/AIDS and Kaposi's sarcoma according to gender, age, current address, occupation, and conjugal status, 2004 to 2015, HUJBB, Belém, Pará State, Brazil

\begin{tabular}{|c|c|c|}
\hline $\begin{array}{l}\text { Epidemiological } \\
\text { characteristics }\end{array}$ & $\begin{array}{l}\text { Absolute } \\
\text { frequency } \mathbf{N}\end{array}$ & $\begin{array}{l}\text { Relative } \\
\text { frequency } \%\end{array}$ \\
\hline \multicolumn{3}{|l|}{ Sex } \\
\hline Male & 41 & 80.4 \\
\hline Female & 10 & 19.6 \\
\hline \multicolumn{3}{|l|}{ Age (years) } \\
\hline $15-29$ & 18 & 35.3 \\
\hline $30-44$ & 23 & 45.1 \\
\hline $45-59$ & 9 & 17.6 \\
\hline$\geq 60$ & 1 & 2.0 \\
\hline \multicolumn{3}{|l|}{ Self-reported race/skin color } \\
\hline White & 5 & 9.8 \\
\hline Brown & 44 & 86.2 \\
\hline Black & 1 & 2.0 \\
\hline Not recorded & 1 & 2.0 \\
\hline \multicolumn{3}{|l|}{ Conjugal status } \\
\hline Single & 44 & 86.3 \\
\hline Married & 5 & 9.8 \\
\hline Divorced & 1 & 2.0 \\
\hline Widow/widower & 1 & 2.0 \\
\hline \multicolumn{3}{|l|}{ Birthplace } \\
\hline Greater Metropolitan Belém & 41 & 80.4 \\
\hline $\begin{array}{l}\text { Other municipalities } \\
\text { (counties) in Pará State }\end{array}$ & 10 & 19.6 \\
\hline \multicolumn{3}{|l|}{ Profession/Occupation } \\
\hline Hairdresser & 7 & 13.7 \\
\hline Self-employed & 4 & 7.8 \\
\hline Student & 3 & 5.9 \\
\hline Homemaker & 3 & 5.9 \\
\hline Not recorded & 5 & 9.8 \\
\hline
\end{tabular}

Source: Research protocol, 2016. 
TABLE 2: Distribution of persons living with HIV/AIDS and Kaposi's sarcoma according to time since HIV diagnosis and use of antiretroviral therapy, 2004-2015, HUJBB, Belém, Pará, Brazil

\begin{tabular}{lcc}
\hline Treatment characteristics & $\begin{array}{l}\text { Absolute } \\
\text { frequency N }\end{array}$ & $\begin{array}{l}\text { Relative } \\
\text { frequency } \%\end{array}$ \\
\hline $\begin{array}{l}\text { Time since HIV } \\
\text { diagnosis < 6 months }\end{array}$ & 30 & 58.8 \\
Yes & 16 & 31.4 \\
No & 5 & 9.8 \\
Not recorded & $\mathbf{5 1}$ & $\mathbf{1 0 0 . 0}$ \\
Total & & \\
Use of antiretroviral therapy & 44 & 86.3 \\
Yes & 7 & 13.7 \\
No & $\mathbf{5 1}$ & $\mathbf{1 0 0 . 0}$ \\
Total & & \\
Antiretroviral therapy & & \\
according to classes & 31 & 70.5 \\
2 NRTI* + NNRTI** & 2 & 4.5 \\
2 NRTI + PI\# & 7 & 15.9 \\
2 NRTI + PI/r $\mu$ & 4 & 9.1 \\
Not recorded & $\mathbf{4 4}$ & $\mathbf{1 0 0 . 0}$ \\
Total & & \\
\hline
\end{tabular}

Source: Research protocol, 2016.

*Nucleoside reverse transcriptase inhibitor; ${ }^{* *}$ Non-nucleoside reverse transcriptase inhibitor; \# Protease inhibitor; $\mu$ Ritonavir-boosted protease inhibitor.

\section{RESULTS}

As mentioned, of the 51 individuals, the majority were male $(80.4 \%)$, ranging in age from 20 to 61 years, living in Greater Metropolitan Belém $(80.4 \%)$, and single $(86.3 \%)$, with hairdresser as the most frequent occupation (13.7\%) (Table 1).

As for time since HIV diagnosis, $58.8 \%$ had been diagnosed recently, i.e., less than six months previously (Table 2). Of these, 44 were on cART, and the mostly widely used regimen was 2 NNRTI + NRTI $(70.5 \%)$.

Concerning the clinical characteristics of the disease, the majority presented disseminated skin lesions (39.2\%), followed by lesions exclusively on the limbs (15.7\%) and on the trunk and limbs $(11.8 \%)$. The most common primary lesions were violaceous macules $(40 \%)$ and violaceous papules (22.5\%) (Table 3, Figures 1 and 2).

Nearly two-thirds $(62.7 \%)$ of the individuals presented visceral involvement $(n=32 / 51)$, and of these, the most frequently affected organ was the stomach $(75 \% ; n=24 / 32)$. Of all the individuals with KS, $24(47.1 \%)$ had indication of chemotherapy after staging of the neoplastic spread to visceral organs and were accompanied by the hospital's Oncology Department after discharge. A total of $25.5 \%$ of the individuals died in hospital.

\section{DISCUSSION}

The study sample included a majority of adult males, with a mean age of 35 years, similar to studies from the 1990s and corroborating a more recent study in which $88 \%$ of the patients were males and with a mean age of 35 years. ${ }^{20-22}$
TABLE 3: Distribution of persons living with HIV/AIDS and

Kaposi's sarcoma according to location of skin lesions, pattern of primary lesions, and visceral involvement, 2004-2015, HUJBB, Belém, Pará, Brazil

\begin{tabular}{|c|c|c|}
\hline Clinical characteristics & $\begin{array}{l}\text { Absolute } \\
\text { frequency }\end{array}$ & $\begin{array}{l}\text { Relative } \\
\text { frequency } \%\end{array}$ \\
\hline \multicolumn{3}{|l|}{ Location of skin lesions } \\
\hline Face & 1 & 2.0 \\
\hline Face and limbs & 1 & 2.0 \\
\hline Oral cavity & 2 & 3.9 \\
\hline Neck and limbs & 1 & 2.0 \\
\hline Trunk & 1 & 2.0 \\
\hline Limbs & 8 & 15.7 \\
\hline Trunk and limbs & 6 & 11.8 \\
\hline Disseminated & 20 & 39.2 \\
\hline Not recorded & 11 & 21.6 \\
\hline Total & 51 & 100.0 \\
\hline \multicolumn{3}{|l|}{ Primary lesion } \\
\hline Violaceous macules & 16 & 40.0 \\
\hline Violaceous papules & 9 & 22.5 \\
\hline Violaceous nodules & 4 & 10.0 \\
\hline Infiltrated plaques & 4 & 10.0 \\
\hline Violaceous tumor & 2 & 5.0 \\
\hline Ulcerative-vegetative lesion & 5 & 12.5 \\
\hline Total & 40 & 100.0 \\
\hline \multicolumn{3}{|l|}{ Visceral involvement } \\
\hline Yes & 32 & 62.7 \\
\hline No & 5 & 9.8 \\
\hline Not reported & 14 & 27.5 \\
\hline Total & 51 & 100.0 \\
\hline \multicolumn{3}{|l|}{ Visceral organs involved } \\
\hline Stomach & 24 & 75.0 \\
\hline Small intestine & 8 & 25.0 \\
\hline Large intestine & 8 & 25.0 \\
\hline Esophagus & 6 & 18.8 \\
\hline Lung & 3 & 9.4 \\
\hline \multicolumn{3}{|l|}{$\begin{array}{l}\text { Chemotherapy performed at } \\
\text { the Oncology Service }\end{array}$} \\
\hline Yes & 24 & 47.1 \\
\hline Not referred & 7 & 13.7 \\
\hline Not recorded & 7 & 13.7 \\
\hline Death during hospitalization & 13 & 25.5 \\
\hline Total & 51 & 100.0 \\
\hline
\end{tabular}

Source: Research protocol, 2016.

Concerning the profession/occupation of KS patients, several studies have shown higher incidence of the disease in individuals with more education, especially health professionals, including dentists, due to the heavy exposure to the saliva of infected patients. ${ }^{22-24}$ In the current study the most common occupation was 


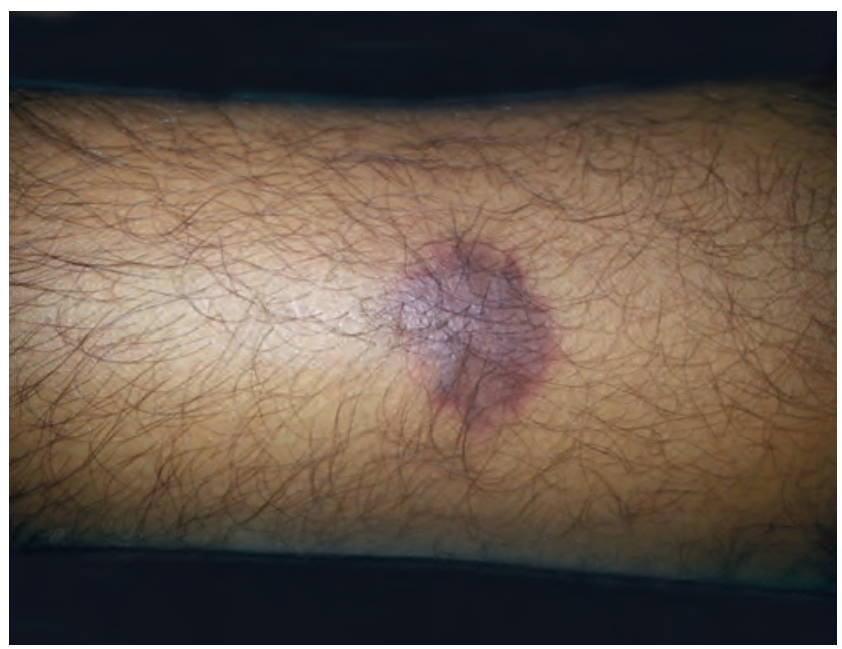

Figure 1: Oval violaceous macule, $2.5 \mathrm{~cm}$ in diameter. Source: Research protocol, authors' files, 2017.

hairdresser. Most patients had completed secondary school. One finding that stands out is the high proportion of single patients $(86.3 \%)$, which raises the question concerning monogamous relationships as a protective factor, as described in the literature, and corroborating various studies on infectious diseases showing that single individuals are much more susceptible to infections from such etiological agents as herpesvirus. ${ }^{25}$

The large proportion of patients from Greater Metropolitan Belém, the state capital of Pará, is consistent with the literature reporting higher incidence of KS and HIV in the capital cities of underdeveloped countries than in the rural areas. Other regions of Pará also have regional hospitals that can receive patients from their vicinities. ${ }^{26}$ Interestingly, in urban areas of developed countries where the human development index is similar to that of undeveloped countries, there are also numerous reports of this coinfection, thus highlighting the importance of social determinants and the fact that knowledge of such determinants can help orient public policies for prevention. ${ }^{27}$

As for time since HIV infection and use of continuous antiretroviral therapy, our results corroborate other studies in the literature. In most of the cases in our study, time since HIV diagnosis was less than a year, so continuous antiretroviral therapy was also recent, which may also have resulted in early diagnosis of KS. ${ }^{28-30}$ However, this disagrees with the high percentage of visceral involvement in this patient sample. This may mean later HIV diagnosis, often made after the emergence of clinical suspicion of cutaneous KS.

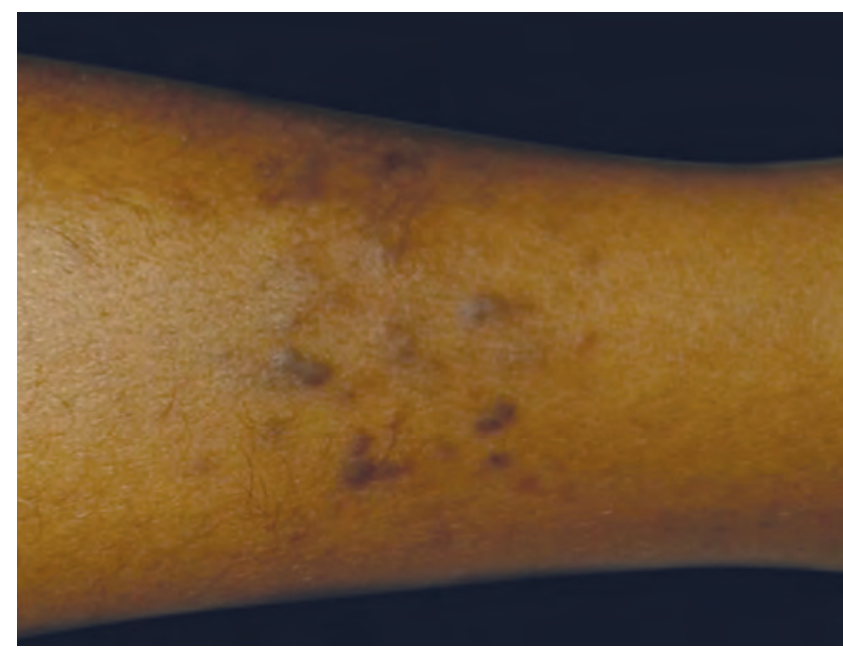

FIGURE 2: Converging violaceous papules located on anterior surface of the leg.

Source: Research protocol, authors' files, 2017.

Early initiation of continuous antiretroviral therapy in HIV patients is known to decrease the risk of disease progression, especially with viral RNA suppression and subsequent increase in CD4 T-lymphocyte count. ${ }^{31,32}$ Treatment adherence should also be discussed at length with the patient, since lack of perfect adherence has been shown to be a risk factor (up to 20-fold) that favors dissemination of the disease and systemic manifestations. ${ }^{33}$

Other clinical features of KS in this study were similar to those reported in the literature, with skin lesions consisting mainly of violaceous macules and papules, suggesting initial KS lesions but not necessarily the absence of visceral lesions. ${ }^{30,32-34}$ Importantly, manifestations in other organ systems can precede skin lesions. ${ }^{34}$ In visceral involvement, the gastrointestinal tract is the most frequently affected system, especially the stomach. $9,30,35$

\section{CONCLUSION}

Although the involvement of the skin manifested in most of the cases was non-exuberant, with initial lesions like macules and papules, many of the patients had already presented visceral involvement, emphasizing the need for careful screening of patients even when skin lesions are subtle or localized.

This study addressed the clinical and epidemiological characteristics of individuals with Kaposi's sarcoma and HIV in an Amazonian population. $\square$ 


\section{REFERENCES}

1. Costa D, Viana PCC, Maciel RP, Gebrim EMMS, Rocha MS. Sarcoma de Kaposi relacionado à síndrome da imunodeficiência adquirida: características do comprometimento hepático na tomografia computadorizada e na ressonância magnética. Radiol Bras. 2017;41:139-40

2. Ohe EM, Padilha MH, Enokihara MM, Almeida FA, Porro AM. Fatal outcome in classic Kaposi's sarcoma. An Bras Dermatol. 2010;85:375-9.

3. Gasparetto TD, Marchiori E, Lourenço S, Zanetti G, Vianna AD, Santos AA, et al. Pulmonary involvement in Kaposi sarcoma: correlation between imaging and pathology. Orphanet J Rare Dis. 2009;4:18.

4. Chang Y, Cesarman E, Pessin MS, Lee F, Culpepper J, Knowles DM, et al. Identification of herpesvirus-like DNA sequences in AIDS-associated Kaposi's sarcoma. Science. 1994;266:1865-9

5. Tappero JW, Conant MA, Wolfe SF, Berger TG. Kaposi's sarcoma. Epidemiology, pathogenesis, histology, clinical spectrum, staging criteria and therapy. J Am Acad Dermatol. 1993;28:371-95

6. Souza VA, Sumita LM, Freire W, Sato HK, Grandi JL, Pierrotti LC, et al. Prevalence of antibodies to human herpesvirus-8 in populations with and without risk for infection in São Paulo State. Braz J Med Biol Res. 2004;37:123-7.

7. Souza VA, Salzano FM, Petzl-Erler ML, Nascimento MC, Mayaud P, Borges JD, J et al. Variations in Human Herpesvirus Type 8 Seroprevalence in Native Americans, South America. Emerg Infect Dis. 2010;16:1003-6.

8. Magri MC, Carbone PH, de los Santos-Fortuna E, Caterino-de-Araujo A. A comparative study of the frequency of antibody and titers against human herpesvirus 8 latent and lytic antigens in "at-risk" individuals and among patients with Kaposi's sarcoma. J Med Virol. 2009;81:1292-7.

9. Batista MD, Ferreira S, Sauer MM, Tomiyama H, Giret MT, Pannuti CS, et al. High Human Herpesvirus 8 (HHV-8) Prevalence, Clinical Correlates and High Incidence among Recently HIV-1-Infected Subjects in Sao Paulo, Brazil. PLoS One. 2009;4:e5613

10. Tiussi RM, Caus AL, Diniz LM, Lucas EA. Kaposi's Sarcoma: clinical and pathological aspects in patients seen at the Hospital Universitário Cassiano Antônio Moraes - Vitória - Espírito Santo - Brazil. An Bras Dermatol. 2012;87:220-7.

11. Santos A. Análise da expressão de genes selecionados do herpesvírus associado ao sarcoma de Kaposi (KSHV) em células TIVE-LTC expostas à proteína Tat do vírus da imunodeficiência humana (HIV-1) [tese]. Botucatu (SP): Universidade Estadual Paulista; 2014. 73 p.

12. Yaghoobi R, Pazyar N, Tavakoli S. Co-existence of multicentric Castleman's disease and Kaposi's sarcoma. Indian J Dermatol. 2015;60:323.

13. Pinto LW, Nunes EP. Simultaneous lymph node involvement by Castleman disease and Kaposi sarcoma. Rev Bras Hematol Hemoter. 2011;33:73-6.

14. Ortega L, Cooper CJ, Otoukesh S, Mojtahedzadeh M, Didia CS, Torabi A, et al. Multicentric Castleman's disease and Kaposi's sarcoma in a HIV-positive patient on highly active antiretroviral therapy. Rare Tumors. 2014;6:98-100.

15. Fonseca B, Bollela V, Neto R. Kaposi's Sarcoma and acquired immunodeficiency syndrome: characteristics of this association including new concepts on pathogenesis and treatment. Medicina (Ribeirão Preto. Online). 1999;32:26-39.

16. Ognibene FP, Steis RG, Macher AM, Liotta L, Gelmann E, Pass HI, et al. Kaposi's sarcoma causing pulmonary infiltrates and respiratory failure in the acquired immunodeficiency syndrome. Ann Intern Med. 1985;102:471-5.

17. Kriggel R. The treatment and natural history of Kaposi's Sarcoma. Ann N Y Acad Sci. 1984;437:447-53
18. Krown SE, Testa MA, Huang J. AIDS-related Kaposi's sarcoma: prospective validation of the AIDS Clinical Trials Group staging classification. AIDS Clinical Trials Group Oncology Committee. J Clin Oncol. 1997;15:3085-92.

19. Beral V, Peterman TA, Berkelman RL, Jaffe HW. Kaposi's sarcoma among persons with AIDS: a sexually transmitted infection? Lancet. 1990;335:123-8.

20. Saraceni V, Talhari CC, Pereira GF, Golub JE, Talhari S, Miranda AE. AIDS-related Kaposi's sarcoma in Brazil: trends and geopolitical distribution. Int J Dermatol. 2013;52:1525-9.

21. Wang J, Stebbing J, Bower M. HIV-Associated Kaposi Sarcoma and Gender. Gend Med. 2007:4:266-73

22. Martin J. Kaposi Sarcoma-Associated Herpesvirus/Human Herpesvirus 8 and Kaposi Sarcoma. Adv Dent Res. 2011;23:76-8.

23. Ziegler J, Newton R, Katangole-Mbidde E, Mbulataiye S, DeCock K, Wabinga H et al. Risk Factors for Kaposi's Sarcoma (KS) in HIV Seropositive Subjects in Uganda. AIDS. 1997;11:1619-26.

24. Vermund SH, Hayes RJ. Combination Prevention: New Hope for Stopping the Epidemic. Curr HIV/AIDS Rep. 2013;10:169-86.

25. Stoebenau K, Nair RC, Rambeloson V, Rakotoarison PG, Razafintsalama V, Labonté $R$. Consuming sex: the association between modern goods, lifestyles and sexual behaviour among youth in Madagascar. Global Health. 2013:9:13.

26. Sutton MY, Gray SC, Elmore K, Gaul Z. Social Determinants of HIV Disparities in the Southern United States and in Counties with Historically Black Colleges and Universities (HBCUs), 2013-2014. PLoS One. 2017:12:e0170714.

27. Pereira P. Investigação do antígeno nuclear latente-1 do herpesvírus humano tipo-8 no sarcoma de Kaposi epidêmico cutâneo e seus simuladores histológicos [tese]. Rio de Janeiro (RJ): Fundação Oswaldo Cruz; 2011. 70 p.

28. Guttman-Yassky E, Bar-Chana M, Yukelson A, Linn S, Friedman-Birnbaum R, Bergman R, et al. Epidemiology of classic Kaposi's sarcoma in the Israeli Jewish population between 1960 and 1998. Br J Cancer. 2003:89:1657-60.

29. Lima C. Sarcoma de Kaposi: características clínico-laboratoriais, estadiamento inicial e desfecho em pacientes com aids atendidos em centro de referência de Recife/PE [tese]. Recife (PE): Universidade Federal de Pernambuco; 2015. 107 p

30. Bower M, Dalla Pria A, Coyle C, Andrews E, Tittle V, Dhoot S, et al. Prospective Stage-Stratified Approach to AIDS-Related Kaposi's Sarcoma. J Clin Oncol. 2014;32:409-14.

31. Cancer Project Working Group for the Collaboration of Observational HIV Epidemiological Research Europe (COHERE) study in EuroCoord. Changing Incidence and Risk Factors for Kaposi Sarcoma by Time Since Starting Antiretroviral Therapy: Collaborative Analysis of 21 European Cohort Studies. Clin Infect Dis. 2016:63:1373-1379.

32. Lupia R, Wabuyia PB, Otiato P, Fang CT, Tsai FJ. Risk factors for Kaposi's sarcoma in human immunodeficiency virus patients after initiation of antiretroviral therapy: A nested case-control study in Kenya. J Microbiol Immunol Infect. 2017;50:781-8.

33. Hengge UR, Ruzicka T, Tyring SK, Stuschke M, Roggendorf M, Schwartz RA, et al. Update on Kaposi's sarcoma and other HHV8 associated diseases. Part 1: epidemiology, environmental predispositions, clinical manifestations, and therapy. Lancet Infect Dis. 2002;2:281-92.

34. Corriça TMC, Caldas MLR. Sarcoma de Kaposi em pacientes com AIDS: estudo de 20 anos de necrópsias em Hospital Universitário. DST- J Bras Doenças Sex Transm. 2009;21:9-11

35. Souza R, Pozzeti E, Oliveira G, Rossi N, Ferraz F, Antonio J. Manifestação clínica do Sarcoma de Kaposi como sinal inicial da Síndrome da Imunodeficiência Adquirida. Arq Ciênc Saúde. 2012;9:30-2.

\section{AUTHORS CONTRIBUTION}

\section{Carla Andréa Avelar Pires}

\section{iD ORCID 0000-0002-0566-9921}

Approval of the final version of the manuscript; Conception and planning of the study; Elaboration and writing of the manuscript: Effective participation in research orientation; Critical review of the manuscript

Marcos Antonio Neves Noronh

iD ORCID 0000-0002-2202-4164

Statistical analysis; Elaboration and writing of the manuscript; Obtaining, analyzing and interpreting the data; Critical review of the manuscript

Julius Caesar Mendes Soares Monteiro

(iD) ORCID 0000-0001-7809-7242

Approval of the final version of the manuscript; Conception and planning of the study Elaboration and writing of the manuscript; Critical review of the manuscript

Albert Luiz Costa da Costa
Statistical analysis; Elaboration and writing of the manuscript; Obtaining, analyzing and
interpreting the data; Critical review of the manuscript
José Maria de Castro Abreu Júnior
Critical review of the literature; Critical review of the manuscript

How to cite this article: Pires CAA, Noronha MAN, Monteiro JCMS, Costa ALC, Abreu Júnior JMC. Kaposi's sarcoma in persons living with HIV/AIDS: a case series in a tertiary referral hospital. An Bras Dermatol. 2018;93(4):524-8. 